\title{
Tracking the direct impact of rainfall on groundwater at Mt. Fuji by multiple analyses including microbial DNA
}

\author{
Ayumi Sugiyama ${ }^{1,2,3}$, Suguru Masuda ${ }^{1}$, Kazuyo Nagaosa $^{1}$, Maki Tsujimura ${ }^{3}$, and Kenji Kato ${ }^{1}$ \\ ${ }^{1}$ Department of Geosciences, Graduate School of Science, Shizuoka University, Shizuoka 422-8529, Japan \\ ${ }^{2}$ Asano Taiseikiso Engineering Co., Ltd., Tokyo 110-0014, Japan \\ ${ }^{3}$ Faculty of Life and Environmental Sciences, University of Tsukuba, Tsukuba 305-8572, Japan
}

Correspondence: Kenji Kato (kato.kenji@shizuoka.ac.jp)

Received: 18 July 2017 - Discussion started: 21 August 2017

Revised: 1 December 2017 - Accepted: 23 December 2017 - Published: 5 February 2018

\begin{abstract}
A total of 2 to 3 million tons of spring water flushes out from the foot of Mt. Fuji, the largest volcanic mountain in Japan. Based on the concept of piston flow transport, residence time of stored groundwater at Mt. Fuji was estimated at $\sim 15-30$ years by the ${ }^{36} \mathrm{Cl} / \mathrm{Cl}$ ratio (Tosaki et al., 2011). This range, however, represents the average residence time of groundwater that was mixed before it flushed out. To elucidate the route of groundwater in a given system, we determined signatures of direct impacts of rainfall on groundwater, using microbial, stable isotopic $\left(\delta^{18} \mathrm{O}\right)$, and chemical analyses (concentration of silica). Chemical analysis of the groundwater gave an average value of the water, which was already mixed with waters from various sources and routes in the subsurface environment. The microbial analysis suggested locations of water origin and paths.

In situ observation during four rainfall events revealed that the stable oxygen isotopic signature obtained from spring water (at $726 \mathrm{~m}$ a.s.1., site $\mathrm{SP}-0 \mathrm{~m}$ ) and shallow groundwater (at $150 \mathrm{~m}$ a.s.1., site $\mathrm{GW}-42 \mathrm{~m}$ ), where the average recharge height from rainfall was $1700-1800 \mathrm{~m}$, became greater than values observed prior to a torrential rain producing more than $300 \mathrm{~mm}$ of precipitation. The concentration of silica decreased after this event. In addition, the abundance of $\mathrm{Bac}$ teria in spring water increased, suggesting the influence of heavy rain. Such changes did not appear when rainfall was less than $100 \mathrm{~mm}$ per event. The above findings indicate a rapid flow of rain through the shallow part of the aquifer, which appeared within a few weeks of torrential rain extracting abundant microbes from soil in the studied geologic setting. Interestingly, we found that after the torrential rain, the abundance of Archaea increased in the deep groundwa-
\end{abstract}

ter at site GW-550 m, 12 km downstream of SP-0 m. However, chemical parameters did not show any change after the event. This suggests that strengthened piston flow caused by the heavy rain transported archaeal particles from the geologic layer along the groundwater route. This finding was supported by changes in constituents of Archaea, dominated by Halobacteriales and Methanobacteriales, which were not seen from other observations. Those two groups of Archaea are believed to be relatively tightly embedded in the geologic layer and were extracted from the environment to the examined groundwater through enforced piston flow. Microbial DNA can thus give information about the groundwater route, which may not be shown by analysis of chemical materials dissolved in the groundwater.

\section{Introduction}

Many hydrological studies have explained runoff processes of groundwater affected by rainfall (e.g., Dunne and Black, 1970; McDonnell et al., 1990; Burns et al., 2001; Tekleab et al., 2014). However, the runoff process of groundwater affected directly by rainfall is not precisely explained. The contribution of rainfall through a subsurface pass to stream water has been estimated by preceding studies, but they did not address the route of groundwater until it affected streamflow.

Development in gene sequence of in situ microbial community enables us to discuss the relation between environment and community constituents (Zhou et al., 2012; Nyyssönen et al., 2014). In addition, population dynamics 
of predominant prokaryote can be discussed with changes in environment. Concerning the subsurface environment, Ben Maamar et al. (2015) recently showed a good correlation between different condition of groundwater with oxygen and dominant microbial population, and they suggested mixing of groundwater. We herein tried to apply microbial DNA analysis to indicate the route of groundwater, focusing on heavy rainfall at the foot of Mt. Fuji located in central Japan, which is the largest Quaternary stratovolcano in Japan, with a peak at $3776 \mathrm{~m}$ a.s.l. At the foot of this mountain we previously found that $\mathrm{pH}$ of groundwater decreased from 7.29 to 7.02 a few weeks after a typhoon in August and September 2011 (total rainfall was $>800 \mathrm{~mm}$ ) (Segawa et al., 2015) at $200 \mathrm{~m}$ a.s.l. This decrease in $\mathrm{pH}$ was probably influenced by low $\mathrm{pH}$ of the rainwater ( $\mathrm{pH}$ from 4.7 to 6.4 ; Watanabe et al., 2006). This rapid decrease in $\mathrm{pH}$ cannot be explained by piston flow transport of groundwater in which newly supplied water pushes out older water preserved in the subsurface bed (e.g., Bethke and Johnson, 2008). Considering the $\mathrm{pH}$ of rainfall at Mt. Fuji, the lowering of groundwater $\mathrm{pH}$ suggested that the newly supplied rainwater mixed directly with groundwater over a period of weeks.

In addition, our preceding microbiological study of groundwater at the foot of Mt. Fuji furnished a clue to estimate possible groundwater routes by finding thermophilic bacterial DNA in spring water, whose temperature was as low as $\sim 10-15^{\circ} \mathrm{C}$ throughout the year (Segawa et al., 2015). Thermophilic prokaryotes are optimally adapted to temperatures $>40^{\circ} \mathrm{C}$. This suggests that at least some of the groundwater source was at a depth of $600 \mathrm{~m}$ or greater, based on a temperature gradient of $4{ }^{\circ} \mathrm{C}$ per $100 \mathrm{~m}$. This depth is far below the lava layer that was taken to be a substantial pool of this groundwater (Tsuchi, 2007). Thus, microbial information can help estimate the route of groundwater.

Following the above findings, we tried to estimate the groundwater route with a focus on heavy rainfall by tracing the signature of direct rainfall impacts. This was done using (i) stable oxygen and hydrogen isotopic analysis to track the movement of water molecules; (ii) chemical analysis of silica concentration in groundwater, which indicates its possible dilution by rainwater with low silica concentration; and (iii) microbial analysis including DNA sequencing to estimate the groundwater route, which may include a possible function of microbes in a given geological environment. Whereas stable isotopic and chemical analyses show average values of the water originated from various sources, microbes transported by groundwater suggest the route and place where they proliferated through their eco-physiological characteristics constrained by their optimal growth condition. In other words, microbial DNA contains information about their route, though the examined water was already blended with various groundwater prior to examination. To elucidate microbial properties in the studied groundwater, we used total direct counting (TDC) of prokaryotes, catalyzed reporter deposition-fluorescence in situ hybridiza- tion (CARD-FISH), 16S rRNA gene-targeted polymerase chain reaction (PCR), denaturing gradient gel electrophoresis (DGGE), and a next-generation sequencing. Here, we first employed microbial analysis to reveal the groundwater route in the shallow and deep subsurface environment.

\section{Materials and methods}

\subsection{Study site}

The study area is at the foot of Mt. Fuji, in the central part of the main island of Japan. Two geologic formations are present (Tsuya, 1968). The upper formation (lava flow and tephra) is permeable and the lower one (mudflow) is impermeable or has low permeability. According to a water flow simulation (using the General Purpose Terrestrial Fluid - FLOWS simulator, or GETFLOWS, Geosphere Environmental Technology Co., Ltd.; Kato et al., 2015; Fig. 1), one of the groundwater bodies at the foot of Mt. Fuji flows toward Suruga Bay together with the Urui River through the western lava flows. We selected this flow as a target study location. Groundwater was sampled at sites SP-0 m (Shibakawa, $726 \mathrm{~m}$ a.s.l., from spring water), GW-42 $\mathrm{m}$ (Yodoshi, $150 \mathrm{~m}$ a.s.l., from shallow well water at $42 \mathrm{~m}$ depth), and GW-550 m (Aoki, $175 \mathrm{~m}$ a.s.1., from deep well water at $550 \mathrm{~m}$ depth). An unusual flush-out of groundwater was observed at GW-42 $\mathrm{m}$ after heavy rainfall from a typhoon in September 2011. Horizontal distance between SP-0 and GW-42 $\mathrm{m}$ was $\sim 12 \mathrm{~km}$. GW-42 and GW-550 m are at a distance of $0.2 \mathrm{~km}$. Rainwater was sampled at five sites with varying altitudes (R1 at 2364, R2 at 1431, R3 at 1081, R4 at 850 , and R5 at $723 \mathrm{~m}$ a.s.1.).

\subsection{Field measurements and sample collection}

Simultaneous observation of rainwater and groundwater was done from June 2012 to November 2014. Spring water was sampled again for gene analysis on 10 March 2015; rainfall was not observed for a few weeks prior to this date. Physical and chemical parameters of groundwater and rainwater were measured directly at the sampling site. In situ measurements of water temperature, $\mathrm{pH}$, electric conductivity (EC), dissolved oxygen (DO), and oxidation reduction potential (ORP) of groundwater were made using an IM-22P (DKKTOA Co., Tokyo, Japan), CM-14P (DKK-TOA Co.), Hach DO meter (Hach Co., Loveland, CO, USA), and RM-20P (DKK-TOA Co.). ORP values were transformed to $\mathrm{E}_{h}$ values (Pt conversion) by Eq. (1). Water temperature, $\mathrm{pH}$, and EC were measured for rainwater.

$$
\begin{aligned}
& E_{\mathrm{h}}(\mathrm{Pt})[\mathrm{mV}]=\mathrm{ORP}[\mathrm{mV}] \\
& +\left(-0.7198 \times \text { temperature }\left[{ }^{\circ} \mathrm{C}\right]+224.36\right)
\end{aligned}
$$

Groundwater was collected directly into sterilized bottles or using a sterilized jug. 


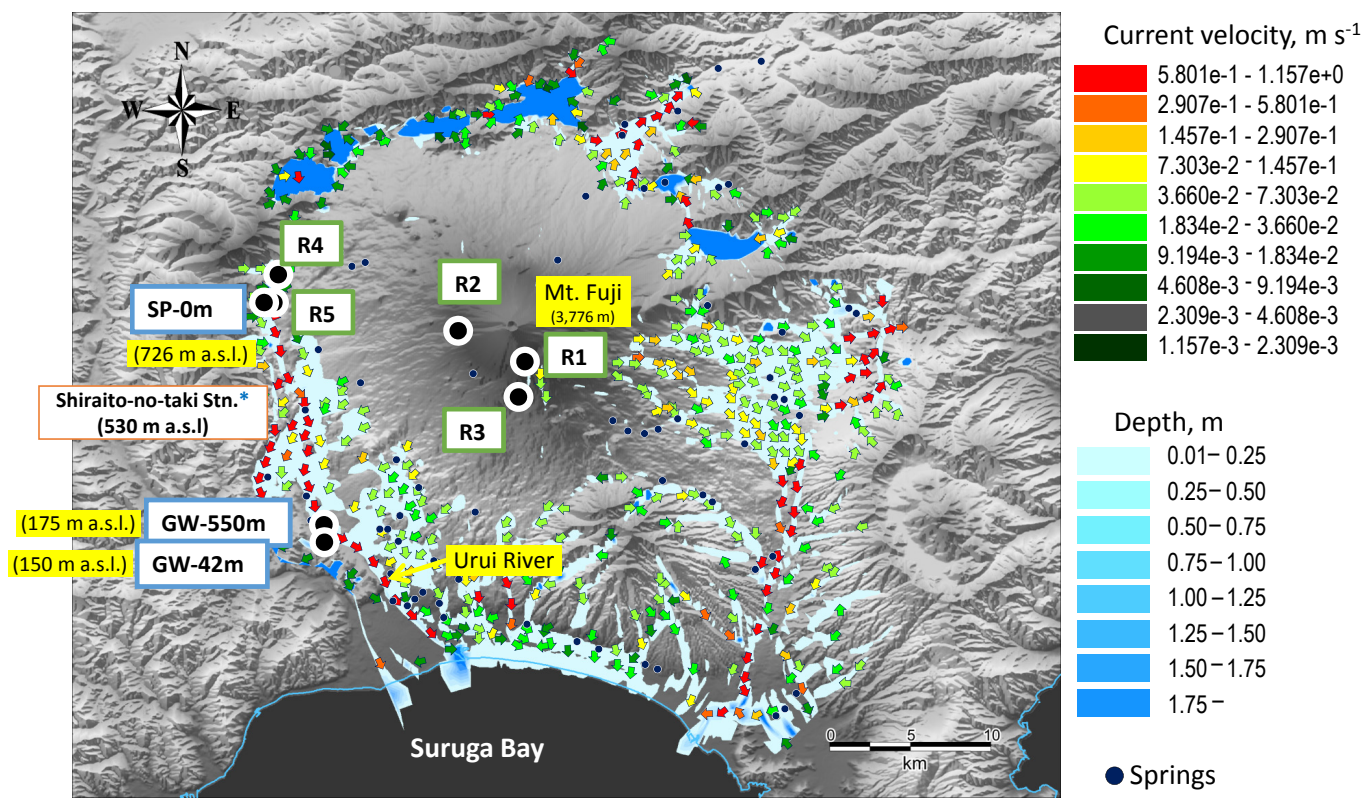

Figure 1. Study sites in western foot of Mt. Fuji. Red arrows indicate main fast flow (GETFLOWS; Kato et al., 2015, partially modified). Precipitation was sampled at R1 to R5. Groundwater was sampled at SP-0, GW-42, and GW-550 m. R1 is located at $2364 \mathrm{~m}$ a.s.1., R2 is at $1431 \mathrm{~m}$ a.s.1., R3 is at $1081 \mathrm{~m}$ a.s.1., R4 is at $850 \mathrm{~m}$ a.s.1., and R5 is at $723 \mathrm{~m}$ a.s.1. SP-0 m, spring water, shows the sampling site of Shibakawa, located at $726 \mathrm{~m}$ a.s.1. GW-42 m, shallow well water obtained from $42 \mathrm{~m}$, is located at Yodoshi at $150 \mathrm{~m}$ a.s. 1 . GW-550 m, deep well water obtained from $550 \mathrm{~m}$, is located at Aoki at $175 \mathrm{~m}$ a.s.l. The asterisk indicates that the amount of precipitation for the studied area was recorded at Shiraito-no-taki Station of Japan Weather Association.

Rainwater for isotopic, chemical, and microbial analysis was collected using 500 and $1000 \mathrm{~mL}$ Pyrex bottles with 300 and $210 \mathrm{~mm}$ funnels, respectively (Hamers et al., 2001; Beiderwieden et al., 2005). Rainwater samplers, prevented from evaporation by a plastic ball in between the bottom of the funnel and glass bottle, were set up at $1.5 \mathrm{~m}$ above ground. To measure silica concentration, rainwater was collected using a plastic jug. The samples were immediately kept cool in the dark until treatment.

\subsection{Isotopic and chemical analysis}

Samples for analysis of stable isotopes $\left({ }^{18} \mathrm{O}\right.$ and $\left.\mathrm{D}\right)$ and major ions $\left(\mathrm{L}^{+}, \mathrm{Na}^{+}, \mathrm{NH}_{4}^{+}, \mathrm{K}^{+}, \mathrm{Mg}^{2+}, \mathrm{Ca}^{2+}, \mathrm{F}^{-}, \mathrm{Cl}^{-}, \mathrm{NO}_{2}^{-}\right.$, $\mathrm{Br}^{-}, \mathrm{SO}_{4}^{2-}, \mathrm{PO}_{4}^{3-}, \mathrm{NO}_{3}^{-}$and $\mathrm{CO}_{3}^{2-}$ ) were filtered through a $0.22 \mu \mathrm{m}$ Millex-GS filter (EMD Millipore, Billerica, MA, USA) and stored at 4 and $-20^{\circ} \mathrm{C}$, respectively. Samples for measurement of silica concentration were stored at $4{ }^{\circ} \mathrm{C}$ until analysis.

Stable isotope ratios of oxygen and hydrogen $\left(\delta^{18} \mathrm{O}, \delta D\right)$ were measured with a water isotope analyzer (Picarro L2130i, L2120-i; Picarro Inc., Santa Clara, CA, USA). The isotopic ratio was calculated from the ring-down time at specific wavelengths, using wavelength-scanned, cavity ring-down spectroscopy technology (Gupta et al., 2009). The $\delta^{18} \mathrm{O}$ and $\delta D$ values are expressed in per mil (\%o) after normalization to the Vienna Standard Mean Ocean Water scale. Analytical errors for $\delta^{18} \mathrm{O}$ and $\delta D$ were 0.025 and $0.1 \%$, respectively.

Concentrations of major dissolved ions were measured by ion chromatograph (ICS-3000, ICS-2100; Thermo Fisher Scientific Inc., Waltham, MA, USA). Dissolved silica concentration was determined by the molybdenum yellow colorimetric method using GeneQuant 100 (GE Healthcare UK Ltd., Buckinghamshire, England).

\subsection{Microbial analysis}

\subsubsection{Microscopic analysis}

TDC was conducted after Porter and Feig (1980) with some modifications to elucidate the abundance of prokaryotes. CARD-FISH was performed after Pernthaler et al. (2002) and Teira et al. (2004) to analyze microbial community structure. Samples for TDC were fixed in $\mathrm{pH}$-neutral formaldehyde (Wako Pure Chemical Industries Ltd., Osaka, Japan). A subsample of groundwater and rainwater was collected on a Nuclepore filter $(0.2 \mu \mathrm{m}$ pore size; GE Healthcare UK Ltd.). Every treatment of groundwater samples was done on a clean bench (AS ONE Co., Osaka, Japan). Cells were stained with 4',6-diamidino-2phenylindole (DAPI, Nacalai Tesque Inc., Kyoto, Japan; final concentration, $0.01 \mu \mathrm{g} \mathrm{mL}^{-1}$ ) and more than 500 prokaryotic cells were counted under epifluorescence microscopy 
(BX51-FLA; Olympus Corp., Tokyo, Japan). Samples for CARD-FISH were fixed in paraformaldehyde (final concentration $3 \%$; Wako Pure Chemical Industries Ltd.). Hybridization was performed at $35^{\circ} \mathrm{C}$ for $2 \mathrm{~h}$ using a horseradish peroxidase (HRP)-labeled Bacteria-specific Eub338 probe (5'GCT GCC TCC CGT AGG AGT-3'; Amann et al., 1990), or $12 \mathrm{~h}$ using a HRP-labeled Archaea-specific ARC915 probe (5'-GTG CTC CCC CGC CAA TTC CT-3'; Stahl and Amann, 1991) or Non915 probe (5'-TCC TTA ACC GCC CCC TCG TG-3'). Numbers of Bacteria and Archaea were counted based on pictures taken under an epifluorescence microscope (BX51-FLA; Olympus) equipped with a digital camera (DP71, Olympus).

\subsubsection{DNA extraction}

Extraction, amplification, and sequencing of DNA were done according to the method of Kimura et al. (2007). A $10 \mathrm{~L}$ sample of groundwater was filtered using a $0.22 \mu \mathrm{m}$ Sterivex-GV filter (EMD Millipore). A $\sim 1.5 \mathrm{~L}$ rainwater sample was filtered using the same filter. Bulk DNA was extracted using the method described by Somerville et al. (1989). Prokaryotic cells were lysed with a solution of lysozyme and proteinase $K$ in Sterivex-GV. Bulk DNA was extracted with phenol. Concentration and purity of extracted DNA were checked by a NanoVue spectrophotometer (GE Healthcare UK Ltd.).

\subsubsection{S rRNA gene amplicon sequencing}

The 16S rRNA genes were amplified by PCR using the primer coded V3-V4 regions Pro341F (5'-TCG TCG GCA GCG TCA GAT GTG TAT AAG AGA CAG CCT ACG GGN BGC ASC AG-3')/Pro805R (5'-GTC TCG TGG GCT CGG AGA TGT GTA TAA GAG ACA GGA CTA CNV GGG TAT CTA ATC C-3') primer set (Claesson et al., 2010; Klindworth et al., 2013; Takahashi et al., 2014). The following reaction mixture (total volume $25 \mu \mathrm{L}$ ) was used: $12.5 \mu \mathrm{L}$ of $2 \times$ buffer, $0.5 \mu \mathrm{L}$ of MightyAmp (Takara Bio Inc., Otsu, Japan), and 5 pmol of each primer. The following PCR conditions were used: an initial denaturation step at $98^{\circ} \mathrm{C}$ for $2 \mathrm{~min}$ followed by 15 cycles of denaturation at $98^{\circ} \mathrm{C}$ for $10 \mathrm{~s}$, annealing at $55^{\circ} \mathrm{C}$ for $15 \mathrm{~s}$, and extension at $68^{\circ} \mathrm{C}$ for $30 \mathrm{~s}$. Amplification was completed with $5 \mathrm{~min}$ at $68^{\circ} \mathrm{C}$. PCR products were purified using the SPRIselect kit (Beckman Coulter, Brea, CA, USA). Sample libraries for sequencing were prepared according to the MiSeq ${ }^{\mathrm{TM}}$ Reagent Kit Preparation Guide (Illumina Inc., San Diego, CA, USA), and nextgeneration sequencing was run using MiSeq. Operational taxonomic units (OTUs) were clustered using Macqiime (v1.9.1) at a $97 \%$ similarity level. Chimeric sequences were detected by Macqiime via ChimeraSlayer. Individual OTUs were assigned based on representative sequences using Classifier from Ribosomal Database Project II (Wang et al., 2007) with Green Genes database (http://greengenes.lbl.gov/). Se- quence data were submitted to the DNA Data Bank of Japan, accession number DRA004571.

\section{Results}

\subsection{Rainfall and environmental parameters}

We studied four rainfall events from 2012 to 2014 at the foot of Mt. Fuji. Annual precipitation in the study area was $1971 \mathrm{~mm}$ in 2013 and $2403 \mathrm{~mm}$ in 2014. In event 1, 17 October 2012 , there was $30 \mathrm{~mm}$ of rain. In event 2, 4-5 September 2013 and 15-16 September 2013 (typhoon), precipitation exceeded $300 \mathrm{~mm}$. In event 3, 10 July 2014, precipitation was $100 \mathrm{~mm}$. In event 4, 5-6 October 2014 and 13-14 October 2014, precipitation was $>300 \mathrm{~mm}$ (Fig. 2a).

Measured environmental parameters of rainwater and groundwater are summarized in Table 1. Temperatures and $\mathrm{pH}$ of rainwater ranged from 10.1 to $31.9^{\circ} \mathrm{C}$ and 3.94 to 6.29 , respectively. The observed range of $\mathrm{pH}$ was slightly acidic. Temperatures of groundwater at SP-0, GW-42, and GW$550 \mathrm{~m}$ were $10.1-20.6^{\circ} \mathrm{C} . \mathrm{pH}, \mathrm{EC}$, and $\mathrm{Eh}(\mathrm{Pt})$ of groundwater at those three sites were $5.84-8.26,49.5-161.5 \mu \mathrm{S} \mathrm{cm}^{-1}$, and $246-497 \mathrm{mV}$, respectively. The degree of saturation with respect with DO concentration of groundwater was 73.0 $100.7 \%$, suggesting that it was nearly saturated or oversaturated.

There was a remarkable rise in temperature and decrease in $\mathrm{pH}$ after a few weeks of event 2 in spring water at SP-0 m, which suggests a direct influence of torrential rainfall on groundwater.

\subsection{Stable isotopic analysis of rainwater and groundwater}

The oxygen isotopic ratio of rainwater was $-6.35 \%$ for event $1,-8.63$ to $-6.63 \%$ o for event $2,-11.52$ to $-9.19 \%$ o for event 3 , and -8.34 to $-4.68 \%$ o for event 4 . That ratio of $\delta^{18} \mathrm{O}$ in groundwater was -11.36 to $-8.63 \%$ o $(n=46)$. The hydrogen isotopic ratio of rainwater and groundwater was -95.19 to $-13.42 \%$ and -76.13 to $-57.31 \%$, respectively.

The oxygen isotopic ratio measured in deep (550 m depth) groundwater at GW-550m was -11.36 to $-10.81 \%$ o $(n=$ $13)$, being smaller than that of spring water at SP-0 $\mathrm{m}(-9.38$ to $-8.63 \% ; n=20)$ and shallow (42 $\mathrm{m}$ depth) groundwater at GW-42 $\mathrm{m}(-9.26$ to $-8.69 \% ; n=13)$. The altitude effect of rainwater was calculated from observation at $-0.25 \%$ o per $100 \mathrm{~m}$ with respect to the oxygen isotopic ratio and $-2.35 \%$ o per $100 \mathrm{~m}$ with respect to the hydrogen isotopic ratio. From those numbers, the major supply of rainwater was expected to be $1700 \mathrm{~m}$ a.s.l. for the spring water and groundwater at SP-0 and GW-42 m, whereas it was $2500 \mathrm{~m}$ a.s.l. for GW$550 \mathrm{~m}$ from the recharge-water line of Mt. Fuji (Yasuhara et al., 2007).

The stable isotope signature of groundwater showed an increase in $\delta^{18} \mathrm{O}$ at SP- $0 \mathrm{~m}$ after events 2 and 4 , from -9.32 


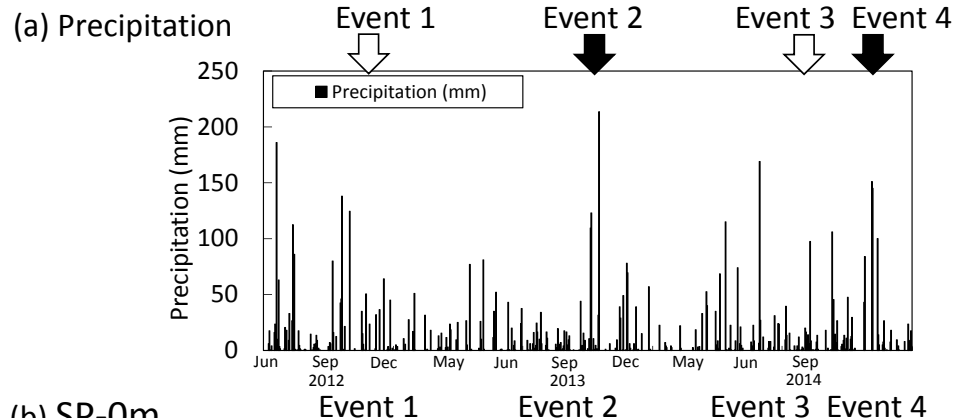

(b) SP-Om
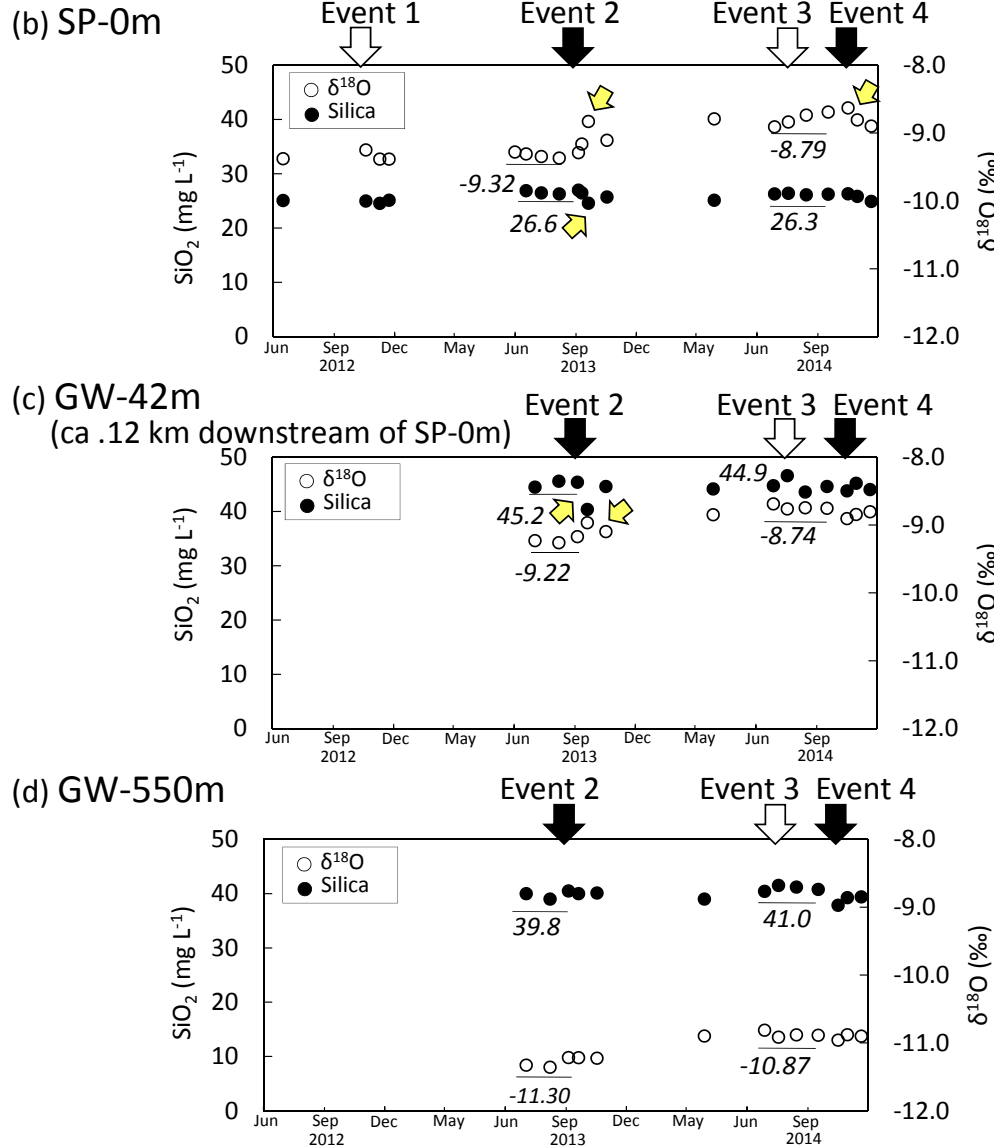

Figure 2. Changes in oxygen isotope ratio, concentration of silica. (a) Precipitation, (b) groundwater at SP-0 m, (c) shallow groundwater at GW-42 m, and (d) deep groundwater at GW-550 m. Black and open arrows indicate the rainfall event: Event 1, Event 2, Event 3 and Event 4. Black arrows indicate the torrential rainfall. Yellow arrows indicate the signature of direct impact of rainfall. The number shows an average value of the plots underlined.

to -8.83 and -8.79 to $-8.63 \%$, respectively, with precipitation exceeding $300 \mathrm{~mm}$ (Fig. 2b). After those events, $\delta^{18} \mathrm{O}$ decreased to the level observed before the event. A similar tendency was observed in shallow groundwater after event 2 at GW-42 m, $\sim 12 \mathrm{~km}$ downstream of SP-0 m (Fig. 2c). However, such a change was not observed in deep groundwater at GW-550 m, located near GW-42 m (Fig. 2d). In contrast with the heavy rainfall, events 1 and 3 with precipitation less than 30 and $100 \mathrm{~mm}$, respectively, did not show increased $\delta^{18} \mathrm{O}$ at SP-0, GW-42, and GW-550 m, except for a slight increase at SP-0 $m$ after event 3 . For the heavy rainfall of event 4 , we ob- served a weak but gradual increase in $\delta^{18} \mathrm{O}$ and subsequent decrease at SP-0 m, but this was not evidenced at GW- $42 \mathrm{~m}$. The average $\delta^{18} \mathrm{O}$ prior to event 4 was larger than that preceding event 2 . This might have caused a weak influence of rainfall on the groundwater, because that influence was expected to have already accumulated in the groundwater.

\subsection{Chemical analysis of rainwater and groundwater}

Although the silica concentration of rainwater was 0.0$3.1 \mathrm{mg} \mathrm{L}^{-1}(n=49)$, that of groundwater was higher, 24.6- 


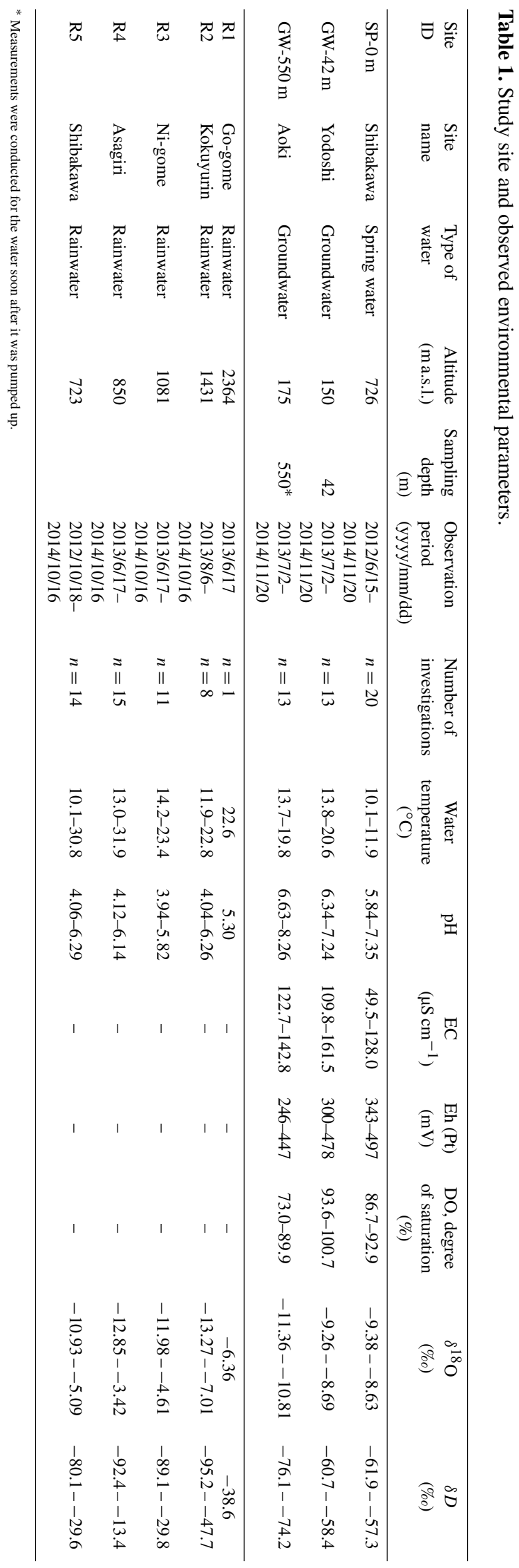

$46.6 \mathrm{mg} \mathrm{L}^{-1}(n=45)$. At SP-0 $\mathrm{m}$, the torrential rainfall of event 2 decreased the silica concentration in groundwater following the event (Fig. 2b). There was a similar finding at GW-42 $\mathrm{m}$, though such a change was not observed in deep groundwater at GW-550 $\mathrm{m}$. There was no apparent decline in silica concentration after events 1 and 3, even at SP-0 m. The heavy rainfall of event 4 also did not cause a subsequent decrease in silica concentration.

Most groundwater so far examined was categorized as $\mathrm{Ca}$ $\mathrm{HCO}_{3}$ type with significant concentration, while GW-550 m was different due to its high concentration of $\mathrm{Na}^{+}$(Supplement Fig. S2 and Table S2). The concentration of analyzed ions in rainwater was very small.

\subsection{Microbial analysis of rainwater and groundwater}

\subsubsection{Abundance of prokaryotes}

Abundance of prokaryotes of rainwater ranged from $(4.04 \pm 0.02) \times 10^{4}$ to $(1.67 \pm 0.08) \times 10^{6}{\text { cells } \mathrm{mL}^{-1}}^{-1}$ $(n=49)$, which significantly exceeded that of groundwater, whose range was $(6.86 \pm 1.53) \times 10^{2}$ to $(1.12 \pm 0.09) \times 10^{4}$ cells mL $\mathrm{mL}^{-1} \quad(n=45)$. The abundance of prokaryote in groundwater was 2 orders of magnitude smaller than that of rainwater. CARD-FISH revealed Bacteria and Archaea respectively comprised 20.7 to $40.0 \%(n=8)$ and 0.8 to $6.6 \%(n=8)$ of the total number of prokaryotes in rainwater for events 2 and 4. Under such ordinary low abundance of prokaryotes in groundwater, there was an apparent influence in event 2 at SP- $0 \mathrm{~m}$. SP-0 $\mathrm{m}$ was located $\sim 1 \mathrm{~km}$ below the average altitude of the recharge zone. Abundance of Bacteria at SP- $0 \mathrm{~m}$ increased sharply after event 2, from $2.6 \times 10^{2}$ cells mL $\mathrm{mL}^{-1}$ to $1.7 \times 10^{3}$ cells mL $\mathrm{m}^{-1}$, and total abundance of prokaryotes increased from $3.21 \times 10^{3}$ cells $\mathrm{mL}^{-1}$ to $1.12 \times 10^{4}$ cells $\mathrm{mL}^{-1}$ (Fig. 3a). A similar phenomenon did not appear at GW-42 m, in shallow groundwater flushed out $\sim 12 \mathrm{~km}$ downstream of SP-0 m (Fig. 3b). In addition, there was a very interesting increase in the abundance of Archaea in deep groundwater at GW-550 m, $12 \mathrm{~km}$ downstream of SP-0 m, where water was obtained from $550 \mathrm{~m}$ depth. The number of Archaea increased from $3.0 \times 10^{1}$ cells mL $\mathrm{mL}^{-1}$ to $1.9 \times 10^{2}$ cells mL $\mathrm{mL}^{-1}$ at GW-550 m (Fig. 3c). A similar phenomenon was observed after event 4, though the response was somewhat weaker than in event 2 .

\subsubsection{Bacterial community constituents}

The number of constituents retrieved by next-generation sequencing at the level of order was 384, 268, and 278 for rainwater (R5), spring water before event 2 (SP-0 m-1) and spring water after event 2 (SP-0 m-2), respectively. Five groups with orders Burkholderiales, Rhizobiales, Sphingobacteriales, Pseudomonadales, and Sphingomonadales comprised about $90 \%$ of all constituents of the R5 community 
(a) SP-Om

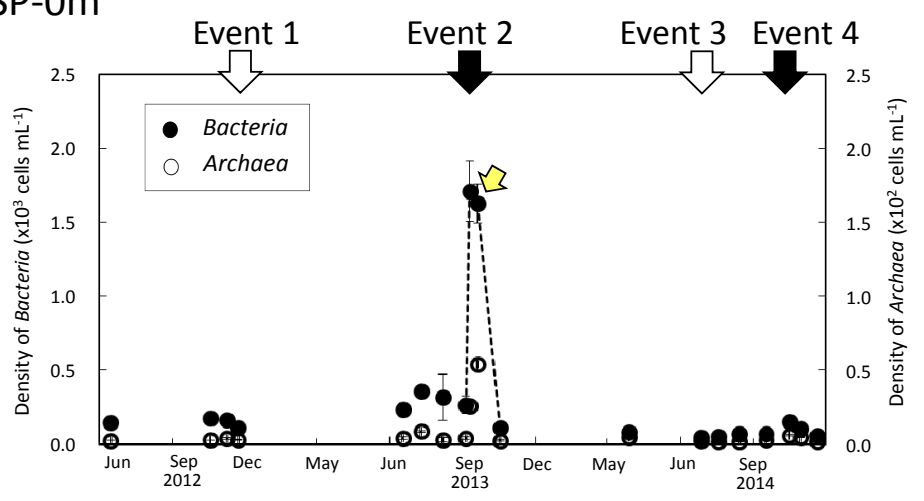

(b) GW-42m

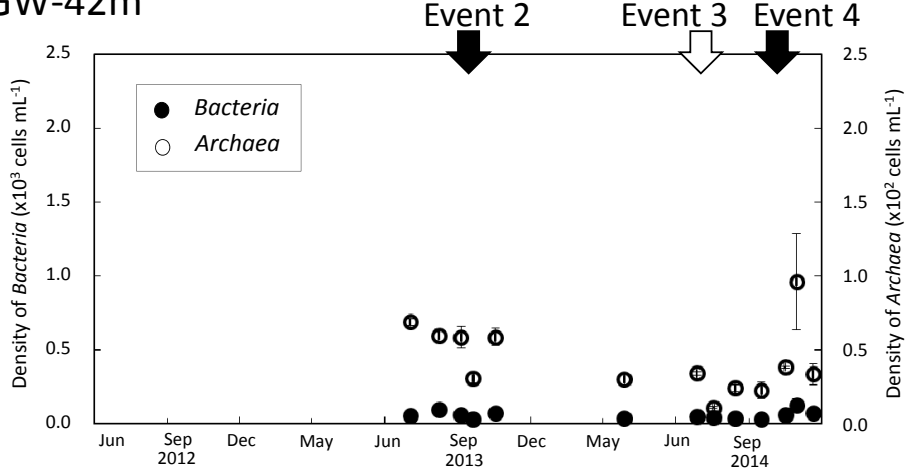

(c) GW-550m

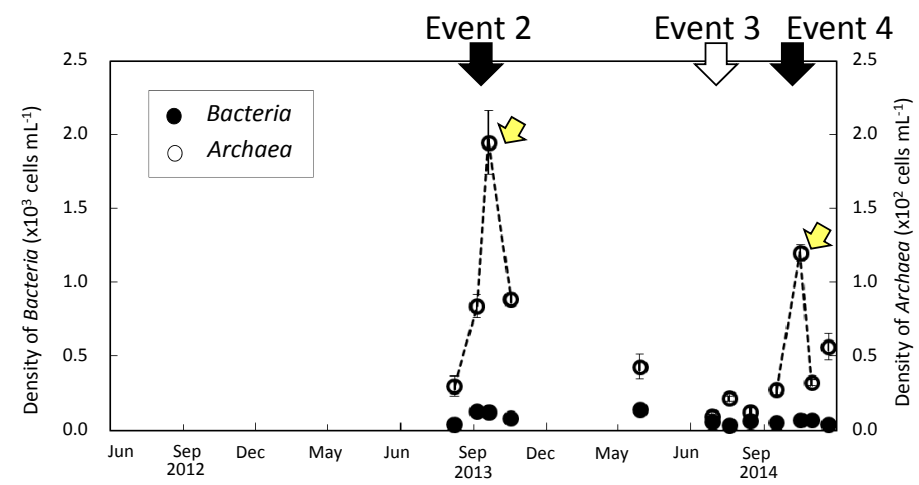

Figure 3. Changes in community structure of prokaryotes in groundwater. (a) Groundwater at SP-0 m, (b) shallow groundwater at GW-42 m, and (c) deep groundwater at GW-550 m. Black and open arrows indicate the rainfall event: Event 1, Event 2, Event 3, and Event 4. Black arrows indicate the torrential rainfall. Yellow arrows indicate the signature of impact of rainfall.

(Fig. 4). In contrast to rainwater, for spring water before event 2 (SP-0 m-1), only Burkholderiales were major constituents among the five major groups retrieved from rainwater, with $17.3 \%$ of the entire bacterial community. The bacterial community in spring water (SP-0 m-1) was more diversified than that in rainwater, R5. A clear difference in bacterial community structure appeared at SP-0 $\mathrm{m}$ after torrential rainfall (SP-0 m-2 in Fig. 4). After event 2, Burkholderiales became apparently dominant in groundwater at SP- $0 \mathrm{~m}$ (58.8\%). Following Burkholderiales, Flavobacteriales was substantial at $8.9 \%$, but had a contribution that did not vary before and after the event. Rhizobiales, Sphingobacteriales,
Pseudomonadales, and Sphingomonadales, which were the major dominant groups in rainwater following Burkholderiales, were apparently not retrieved from the spring water at SP-0 $\mathrm{m}$ after event 2. In contrast, Bdellovibrionales and Bacillales, which were not a major constituent at SP-0 m before that event, became dominant after the torrential rainfall.

\subsubsection{Archaeal community constituents}

We examined the archaeal community, focusing on deep groundwater at GW-550 m, where a remarkable increase was observed in the abundance of Archaea after event 2. 


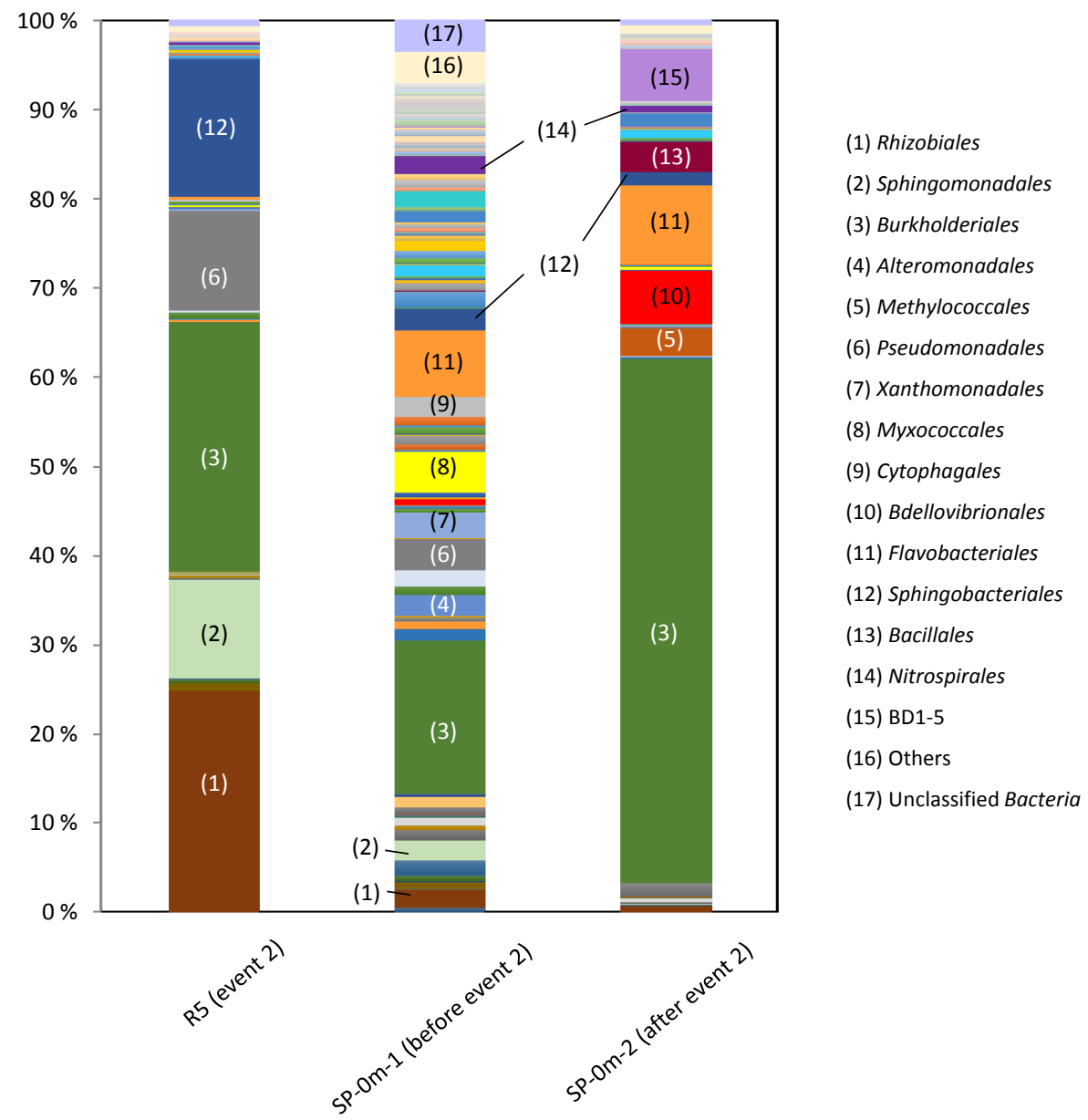

Figure 4. Relative abundance of bacterial orders in each event by next-generation sequencing analysis.

Next-generation sequencing retrieved 12 major groups of $\mathrm{Ar}$ chaea at the level of order for each analyzed sample. Rainwater (R5 in Fig. 5) comprised WCHD3-30 and YLA114 belonging to Parvarchaeota, E2 belonging to Thermoplasmata, unclassified Euryarchaeota, Cenarchaeales, unclassified MBGA (Crenarchaeota), and Micrarchaeles. WCHD330 and YLA114 also dominated in deep groundwater of GW$550 \mathrm{~m}-1$ in the non-rainy period, followed by E2 and Cenarchaeales. The relative proportion of each order group did not vary much after event 4 (GW-550m-3) and the nonrainy period (GW-550 m-1). However, a few weeks following the torrential rainfall of event 2 (GW-550 m-2), Halobacteriales and Methanobacteriales were predominant in the deep groundwater. These relative constituents to the whole community were clearly different from other results.

\section{Discussion}

Tracer hydrology studies of rainfall-runoff processes have revealed the mixing process of rainfall and groundwater in stream water shortly after heavy rain in a range from days to weeks (e.g., Pearce et al., 1986; McDonnell, 1990; Silliman and Booth, 1993; Blume et al., 2008). A sharp decrease in $\mathrm{pH}$ of spring water influenced by heavy rainfall, suggesting a direct effect of rainwater on groundwater, was observed at the foot of Mt. Fuji (Segawa et al., 2015). Following these studies, we investigated heavy $(>300 \mathrm{~mm})$ and light $(100 \mathrm{~mm})$ rain at the foot of volcanic Mt. Fuji at sites SP-0 and GW$42 \mathrm{~m}$ (shallow groundwater) and GW-550 m (deep groundwater), where average recharge of rainfall and snowfall was estimated between 1700 and $2500 \mathrm{~m}$ a.s.1.

We found fast flow of groundwater caused by torrential typhoon rainfall in multiple analyses, including those of microbes. Rainwater exceeding $300 \mathrm{~mm}$ traversed the very shallow portion of the subsurface aquifer and appeared 2 weeks after the event at SP- $0 \mathrm{~m}$. That site is $\sim 1 \mathrm{~km}$ lower in altitude and $\sim 5-7 \mathrm{~km}$ downstream horizontally from the average recharge area of the rainfall. This finding was deduced from the movement of microbial particles and of water molecules tracked by the stable isotope signature of $\delta^{18} \mathrm{O}$, as well as measurement of dissolved silica concentration. The silica concentration in groundwater is ascribable to the extraction 


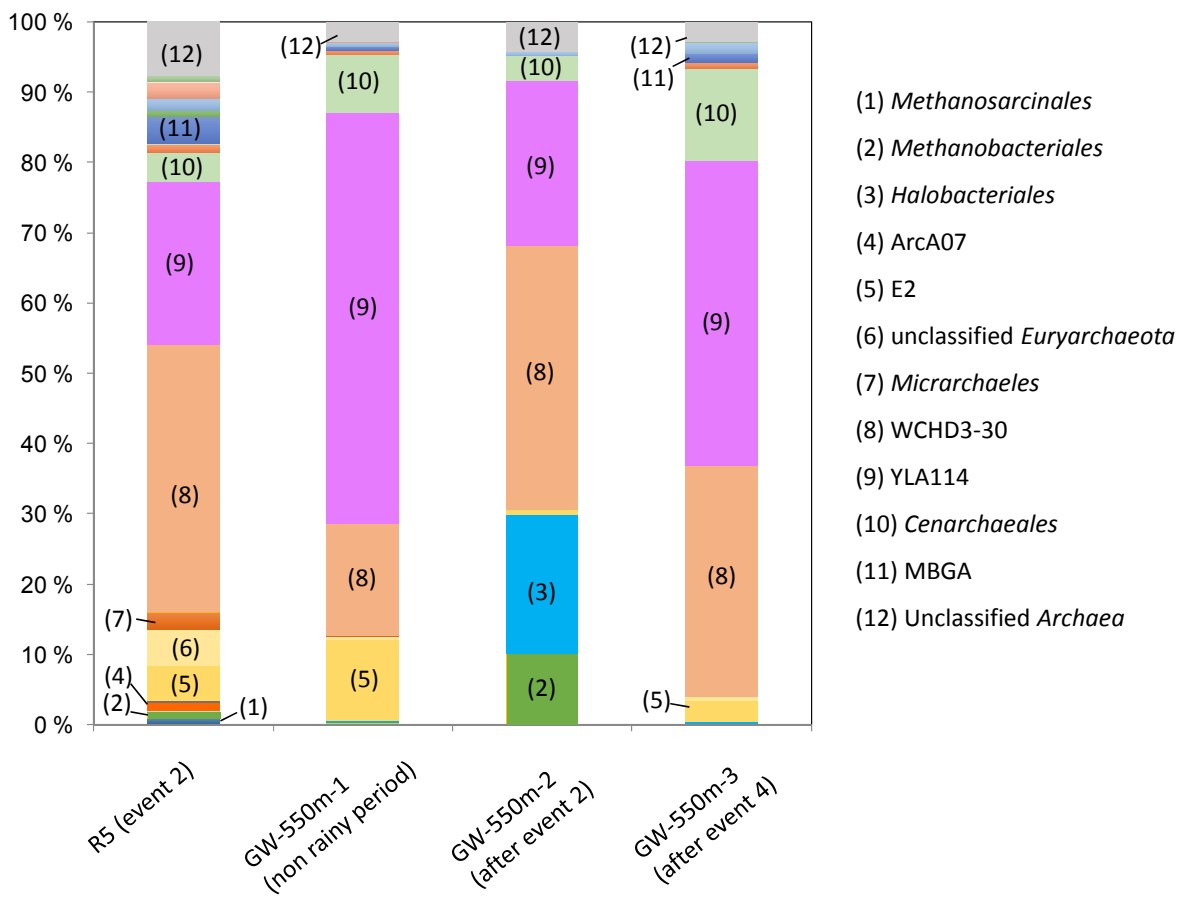

Figure 5. Relative abundance of archaeal orders in each event by next-generation sequencing analysis.

of silicate from soil and rock (Wels et al., 1991; Asano et al., 2003). Thus, decrease in that concentration in groundwater after torrential rain suggests that the flow of groundwater was substantially faster than usual, or a dilution of the concentration by great amounts of infiltrated water. Rapid flow of groundwater was also detected in shallow groundwater at GW- $42 \mathrm{~m}$, which was $\sim 600 \mathrm{~m}$ below the altitude of SP- $0 \mathrm{~m}$ and $\sim 12 \mathrm{~km}$ downstream. This finding was associated with an increase in $\delta^{18} \mathrm{O}$ and decline in silica concentration.

The effect of torrential rainfall was also clearly detected by a sharp increase in the abundance of Bacteria at site SP$0 \mathrm{~m}$. An apparent predominance in the bacterial community of Burkholderiales with high density suggests incorporation of microbes from soil through extraction by enforced flow rate, because the abundance of prokaryotes in soil is about 4 or 5 orders of magnitude greater than that of groundwater (reviewed by Whitman et al., 1998), and Burkholderiales is known to inhabit the soil environment (Garrity et al., 2005a). Direct incorporation of microbes from rainwater (Fig. 4, R5 and SP-0 m-2) is another possibility. Additional analysis with DGGE showed that Herbaspirillum sp. belonging to Burkholderiales was retrieved from SP- $0 \mathrm{~m}$ spring water 2 weeks and 5 days after event 2 (DGGE, Table S3). Infiltration of microbes from the soil matrix, however, seems more likely, because the second, third, and fourth dominant groups of Bacteria in rainwater, Rhizobiales, Sphingomonadales and Pseudomonadales were not significantly retrieved from the spring water after event 2 . Such extraction might increase the relative abundance of Bdellovibrionales, including a typical soil dweller such as Peredibacter starrii in groundwater (Davidov and Jurkevitch, 2004), a group known to generally inhabit the soil environment (Garrity et al., 2005b).

Furthermore, sequences affiliated with thermophilic bacteria inhabited under the temperature exceeding $40{ }^{\circ} \mathrm{C}$ were scarcely retrieved from the samples of the examined SP- $0 \mathrm{~m}$ after event 2 . This finding supports the assertion that enforced piston flow through a deep subsurface zone $>600 \mathrm{~m}$ exceeding $40^{\circ} \mathrm{C}$ was not considerable for the sample examined. Viral particles have previously been used as a tracer of water movement. Hunt et al. (2014) showed preferential flow paths using this method. Viral particles only provide information on groundwater flow paths, whereas microbial analysis including DNA provides additional information on the location of origin of the microbes and the magnitude of impact of water flow on microbes extracted from geologic layers. Thus, microbial analysis can give insight into the route of groundwater through both shallow and deep environments. The latter is discussed below.

In contrast to the findings for shallow groundwater and spring water, no direct influence of torrential rainfall was detected in either the stable isotope signature or concentration of silica in deep groundwater at GW-550 $\mathrm{m}(\sim 12 \mathrm{~km}$ downstream of SP-0 m) after event 2. Considering the difference of horizontal distance and depth from which water was sampled between GW-42 and GW-550 m, the direct impact of rainfall from the observation is expected to be barely noticeable at $550 \mathrm{~m}$ depth. 
However, we observed an interesting increase in abundance of Archaea at GW-550m 2 weeks after event 2, which was supported by an apparent change in constituents of archaeal OTUs. Halobacteriales, comprised of $99.7 \%$ Haloarcula, which inhabit environments with high concentrations of sodium, and Methanobacteriales, comprised of 97.4\% Methanothermobacter, a strict anoxic methane producer, were dominant members after the torrential rainfall. Increasing in abundance of such archaea can be supported by the finding that archaeal abundance increased with depth in both terrestrial (Kato et al., 2009) and marine (Lipp et al., 2008, Inagaki et al., 2015) subsurface environments. Deep groundwater in the study area contained high concentrations of $\mathrm{Na}^{+}$, from 14.3 to $14.6 \mathrm{mg} \mathrm{L}^{-1}(n=13)$, while these were 5.3 to $7.8 \mathrm{mg} \mathrm{L}^{-1}(n=33)$ in groundwater at SP-0 $\mathrm{m}$ and GW-42 m (Fig. S2). Thus, not only strict anaerobic but also halophilic archaea may be abundant within the deep subsurface environment of the study area, although they were not retrieved from groundwater in other examinations, likely because they were embedded in the matrix of geologic layers (Flynn et al., 2008). An augmented flow rate caused by torrential rainfall might have extracted Halobacteriales and Methanobacteriales from the matrix of those layers into the studied groundwater (Fig. 5). In contrast to the spring water $(\mathrm{SP}-0 \mathrm{~m})$, some sequences affiliated with thermophilic bacteria were retrieved from the deep groundwater (GW$550 \mathrm{~m}$ ), which suggested microbes in the deep groundwater contained in situ populations. This suggests that strengthened piston flow caused by the heavy rain transported archaeal particles from the deep geologic layer along the groundwater route.

A possible reason why there was no apparent influence of heavy rain on microbial particles in groundwater at GW$42 \mathrm{~m}, \sim 12 \mathrm{~km}$ downstream of SP- $0 \mathrm{~m}$, may be attributable to the trapping of microbial particles by soil and lava across the flow trajectory. A question remains as to whether in situ population change through the growth in groundwater could be explained by their estimated growth rates. The doubling time of prokaryotes in the groundwater was estimated at 85 days, from the observed frequency of dividing cells to the entire population (Newell and Christian, 1981). Thus, the possibility of altered populations via growth within a few weeks may be small. Microbes observed in the groundwater may represent the original locations where they grew.

Wels et al. (1991) separated streamflow into three components - surface water, soil water, and groundwater - using a two-step separation with stable isotopic ratios and silica concentration. Based on their method, an estimated 21 and $5 \%$ of water in the subsurface environment at SP-0 and GW-42 m, respectively, was attributed to soil water following event 2 . The effect of soil water at SP- $0 \mathrm{~m}$ was estimated to be stronger than that at GW-42 $\mathrm{m}$. This difference appeared in microbial abundance and constituents as well as in water molecule movement. This supports the sudden appearance of rapid flow through the shallow aquifer consisting partly of soil layers in groundwater at SP-0 $\mathrm{m}$. This phenomenon was driven by heavy rainfall.

In contrast, direct and rapid effects of rainwater movement into groundwater were not observed for weak rainfall, as evidenced by the results of events 1 and 3 . However, a question remains as to why an impact similar to event 2 was not observed for another heavy rainfall, that of event 4 . The impact of rainfall before event 4 persisted, as suggested by a stronger $\delta^{18} \mathrm{O}$ signature, which might have masked that impact (Fig. 2).

In addition to the chemical analyses of groundwater, we showed that microbes could show the route of groundwater in the invisible subsurface environment.

\section{Conclusions}

Chemical analyses using stable isotopes and dissolved ions show the properties of the groundwater mixed throughout the route it flowed. In contrast, microbial particles suggest the locations where they were incorporated in the groundwater as far as they survived. Thus, microbial analysis can provide information about the origin and route of the groundwater.

Next-generation gene sequencing provides detailed information of high resolution on the examined microbial community constituents, which was never attained by the conventional gene sequencing technique targeting small subunit ribosomal DNA. Previous conventional gene sequencing does not give quantitative information on microbial community constituents. Here, we first showed the possibility to trace the route of groundwater using a next-generation sequencing analysis of Bacteria and Archaea for the event of heavy rainfall. Bacterial abundance and community constituents showed that torrential rainfall caused rapid flow of rainwater through the shallow part of the aquifer, and archaeal abundance and constituents suggested fast and accelerated piston flow in deep groundwater within a few weeks after that rainfall. The former finding was mostly ascertained by the chemical analysis, but the latter finding was not shown by chemical analysis.

Data availability. Other physico-chemical data of springwater and groundwater obtained by our laboratory are available from our home page: https://wwp.shizuoka.ac.jp/geomicrobial-ecology/ field/.

\section{The Supplement related to this article is available online at https://doi.org/10.5194/bg-15-721-2018-supplement.}

Competing interests. The authors declare that they have no conflict of interest. 
Acknowledgements. This study was supported by a Grant-in-Aid for Scientific Research from the Japan Society for the Promotion of Science (JSPS KAKENHI grant number JP26257402) and a research fund of the River Front Research Institute. This study was conducted by the support of Joint Research Grant for Environmental Isotope Study of the Research Institute for Humanity and Nature. 16S rRNA gene amplicon sequencing was carried out at the Functional Genomics Section, Research Institute of Green Science and Technology, Shizuoka University.

Edited by: Syed Wajih Ahmad Naqvi

Reviewed by: Nobuhito Ohte and one anonymous referee

\section{References}

Amann, R. I., Binder, B. J., Olson, R. J., Chisholm, S. W., Devereux, R., and Stahl, D. A.: Combination of 16S ribosomal-RNAtargeted oligonucleotide probes with flow-cytometry for analyzing mixed microbial-populations, Appl. Environ. Microb., 56, 1919-1925, 1990.

Asano, Y., Uchida, T., and Ohte, N.: Hydrologic and geochemical influences on the dissolved silica concentration in natural water in a steep headwater catchment, Geochim. Cosmochim. Ac., 67, 1973-1989, https://doi.org/10.1016/S0016-7037(02)01342X, 2003.

Beiderwieden, E., Wrzesinsky, T., and Klemm, O.: Chemical characterization of fog and rain water collected at the eastern Andes cordillera, Hydrol. Earth Syst. Sci., 9, 185-191, https://doi.org/10.5194/hess-9-185-2005, 2005.

Ben Maamar, S., Aquilina, L., Quaiser, A., Pauwels, H., MichonCoudouel, S., Vergnaud-Ayraud, V., Labasque, T., Roques, C., Abbott, B. W., and Dufresne, A.: Groundwater isolation governs chemistry and microbial community structure along hydrologic flowpaths, Front. Microbiol., 6, 1457, https://doi.org/10.3389/fmicb.2015.01457, 2015.

Bethke, C. M. and Johnson, T. M.: Groundwater age and groundwater age dating, Annu. Rev. Earth Pl. Sc., 36, 121-152, https://doi.org/10.1146/annurev.earth.36.031207.124210, 2008.

Burns, D. A., McDonnell, J. J., Hooper, R. P., Peters, N. E., Freer, J. E., Kendall, C., and Beven, K.: Quantifying contributions to storm runoff through end-member analysis and hydrologic measurements at the Panola Mountain Research Watershed (Georgia, USA), Hydrol. Process., 15, 1903-1924, https://doi.org/10.1002/hyp.246, 2001.

Blume, T., Zehe, E., and Bronstert, A.: Investigation of runoff generation in a pristine, poorly gauged catchment in the Chilean Andes II: Qualitative and quantitative use of tracers at three spatial scales, Hydrol. Process., 22, 3676-3688, https://doi.org/10.1002/hyp.6970, 2008.

Claesson, M. J., Wang, Q., O'Sullivian, O., Greene-Diniz, R., Cole, J. M., Ross, R. P., and O'Toole, P. W.: Comparison of two next-generation sequencing technologies for resolving highly complex microbiota composition using tandem variable 16S rRNA gene regions, Nucleic Acids Res., 38, e200, https://doi.org/10.1093/nar/gkq873, 2010.

Davidov, Y. and Jurkevitch, E.: Diversity and evolution of Bdellovibrio-and-like organisms (BALOs), reclassification of Bacteriovorax starrii as Peredibacter starrii gen. nov., comb. nov., and description of the Bacteriovorax-Peredibacter clade as Bacteriovoracaceae fam. nov., Int. J. Syst. Evol. Microbiol., 54, 1439-1452, https://doi.org/10.1099/ijs.0.02978-0, 2004.

Dunne, T. and Black, R. D.: Partial area contributions to storm runoff in a small New England watershed, Water Resour. Res., 6, 1296-1311, https://doi.org/10.1029/WR006i005p01296, 1970.

Flynn, T. M., Sanford, R. A., and Bethke, C. M.: Attached and suspended microbial communities in a pristine confined aquifer, Water Resour. Res., 44, W07425, https://doi.org/10.1029/2007WR006633, 2008.

Garrity, G. M., Bell, J. A., and Lilburn, T.: Order I. Burkholderiales ord. nov., in: Bergey's Mannual of Systematic Bacteriology, edited by: Brenner, D. J., Krieg, N. R., Staley, J. T., and Garrity, G. M., 2nd Edn., Vol. 2, Springer Verlag, New York, 575-763, 2005a.

Garrity, G. M., Bell, J. A., and Lilburn, T.: Order VII. Bdellovibrionales ord. nov., in: Bergey's Mannual of Systematic Bacteriology, edited by: Brenner, D. J., Krieg, N. R., Staley, J. T., and Garrity, G. M., 2nd Edn., Vol. 2, Springer Verlag, New York, 1040-1058, 2005b.

Gupta, P., Noone, D., Galewsky, J., Sweeney, C., and Vaughn, B. H.: Demonstration of high-precision continuous measurements of water vapor isotopologues in laboratory and remote field deployments using wavelength-scanned cavity ring-down spectroscopy (WS-CRDS) technology, Rapid Commun. Mass Sp., 23, 25342542, https://doi.org/10.1002/rcm.4100, 2009.

Hamers, T., Smit, M. G. D., Murk, A. J., and Koeman, J. H.: Biological and chemical analysis of the toxic potency of pesticides in rainwater, Chemosphere, 45, 609-624, https://doi.org/10.1016/S0045-6535(01)00017-0, 2001.

Hunt, R. J., Borchardt, M. A., and Bradbury, K. R.: Viruses as groundwater tracers: using ecohydrology to characterize short travel times in aquifers, Ground Water, 52, 187-193, https://doi.org/10.1111/gwat.12158, 2014.

Inagaki, F., Hinrichs, K.-U., Kubo, Y., Bowles, M. W., Heuer, V. B., Hong, W.-L., Hoshino, T., Ijiri, A., Imachi, H., Ito, M., Kaneko, M., Lever, M. A., Lin, Y.-S., Methe, B. A., Morita, S., Morono, Y., Tanikawa, W., Bihan, M., Bowden, S. A., Elvert, M., Glombitza, C., Gross, D., Harrington, G. J., Hori, T., Li, K., Limmer, D., Liu, C.-H., Murayama, M., Ohkouchi, N., Ono, S., Park, Y.-S., Phillips, S. C., Prieto-Mollar, X., Purkey, M., Riedinger, N., Sanada, Y., Sauvage, J., Snyder, G., Susilawati, R., Takano, Y., Tasumi, E., Terada, T., Tomaru, H., Trembath-Reichert, E., Wang, D. T., and Yamada, Y.: Exploring deep microbial life in coal-bearing sediment down to $\sim 2.5 \mathrm{~km}$ below the ocean floor, Science, 349, 420-424, https://doi.org/10.1126/science.aaa6882, 2015.

Kato, K., Nagaosa, K., Kimura, H., Katsuyama, C., Hama, K., Kunimaru, T., Tsunogai, U., and Aoki, K.: Unique distribution of deep groundwater bacteria constrained by geological setting, Environ. Microbiol. Rep., 1, 569-574, https://doi.org/10.1111/j.17582229.2009.00087.x, 2009.

Kato, K., Okumura, T., Segawa, T., Unno, T., Greenidge, D., Nishioka, T., Mori, K., Tosaka, H., and Nagaosa, K.: Unveiled groundwater flushing from the deep seafloor in Suruga Bay, Limnology, 16, 79-83, https://doi.org/10.1007/s10201-014-0445-0, 2015.

Kimura, H., Ishibashi, J. I., Masuda, H., Kato, K., and Hanada, S.: Selective phylogenetic analysis targeting 16S rRNA 
genes of hyperthermophilic archaea in the deep-subsurface hot biosphere, Appl. Environ. Microbiol., 73, 2110-2117, https://doi.org/10.1128/AEM.02800-06, 2007.

Klindworth, A., Pruesse, E., Schweer, T., Peplies, J., Christian, Q., Horn, M., and Glöckner, F. O.: Evaluation of general 16S ribosomal RNA gene PCR primers for classical and net-generation sequencing-based diversity studies, Nucleic Acids Res., 41, e1, https://doi.org/10.1093/nar/gks808, 2013.

Lipp, J. S., Morono, Y., Inagaki, F., and Hinrichs, K. U., Significant contribution of Archaea to extant biomass in marine subsurface sediments, Nature, 454, 991-994, https://doi.org/10.1038/nature07174, 2008.

McDonnell, J. J.: A rationale for old water discharge through macropores in a steep, humid catchment, Water Resour. Res., 26, 2821-2832, https://doi.org/10.1029/WR026i011p02821, 1990.

McDonnell, J. J., Bonell M, Stewart, M. K., and Pearce, A. J.: Deuterium variations in storm rainfall: Implications for stream hydrograph separation, Water Resour. Res., 26, 455-458, https://doi.org/10.1029/WR026i003p00455, 1990.

Newell, S. Y. and Christian, R. R.: Frequency of dividing cells as an estimator of bacterial productivity, Appl. Environ. Microbiol., 42, 23-31, 1981.

Nyyssönen, M., Hultman, J., Ahonen, L., Kukkonen, I., Paulin, L., Laine, P., Itävaara, M., and Auvinen, P.: Taxonomically and functionally diverse microbial communities in deep crystalline rocks of the Fennoscandian shield, ISME J., 8, 126-138, https://doi.org/10.1038/ismej.2013.125, 2014.

Pearce, A. J., Stewart, M. K., and Sklash, M. G.: Storm runoff generation in humid headwater catchments: 1 . Where does water come from?, Water Resour. Res., 22, 1263-1272, https://doi.org/10.1029/WR022i008p01263, 1986.

Pernthaler, A., Pernthaler, J., and Amann, R.: Fluorescence in situ hybridization and catalyzed reporter deposition for the identification of marine bacteria, Appl. Environ. Microbiol., 68, 3094-,3101, https://doi.org/10.1128/AEM.68.6.3094-3101.2002, 2002.

Porter, K. G. and Feig, Y. S.: The use of DAPI for identifying and counting aquatic microflora, Limnol. Oceanogr., 25, 943-948, https://doi.org/10.4319/lo.1980.25.5.0943, 1980.

Segawa, T., Sugiyama, A., Kinoshita, T., Sohrin, R., Nakano, T., Nagaosa, K., Greenidge, D., and Kato, K.: Microbes in groundwater of a volcanic mountain, Mt. Fuji; $16 \mathrm{~S}$ rDNA phylogenetic analysis as a possible indicator for the transport routes of groundwater, Geomicrobiol. J., 32, 677-688, https://doi.org/10.1080/01490451.2014.991811, 2015.

Silliman, S. E. and Booth, D. F.: Analysis of time-series measurements of sediment temperature for identification of gaining vs losing portions of Juday-creek, Indiana, J. Hydrol., 146, 131148, https://doi.org/10.1016/0022-1694(93)90273-C, 1993.

Somerville, C. C., Knight, I. T., Straube, W. L., and Colwell, R. R.: Simple, rapid method for direct isolation of nucleic-acids from aquatic environments, Appl. Environ. Microbiol., 55, 548-554, 1989.
Stahl, D. A. and Amann, R. I.: Development and application of nucleic acid probes, in: Nucleic acid techniques in bacterial systematics, edited by: Stackebrandt, E. and Goodfellow, M., Wiley, J., John Wiley \& Sons Ltd., Chichester, 205-248, 1991.

Takahashi, S., Tomita, J., Nishioka, K., Hisada, T., and Nishijima, M.: Development of a prokaryotic universal primer for simultaneous analysis of Bacteria and Archaea using next-generation sequencing, PLoS One, 9, e105592, https://doi.org/10.1371/journal.pone.0105592, 2014.

Teira, E., Reinthaler, T., Pernthaler, A., Pernthaler, J., and Herndl, G. J.: Combining catalyzed reporter depositionfluorescence in situ hybridization and microautoradiography to detect substrate utilization by bacteria and archaea in the deep ocean, Appl. Environ. Microbiol., 70, 4411-4414, https://doi.org/10.1128/AEM.70.7.4411-4414.2004, 2004.

Tekleab, S., Wenninger, J., and Uhlenbrook, S.: Characterisation of stable isotopes to identify residence times and runoff components in two meso-scale catchments in the Abay/Upper Blue Nile basin, Ethiopia, Hydrol. Earth Syst. Sci., 18, 2415-2431, https://doi.org/10.5194/hess-18-2415-2014, 2014.

Tosaki, Y., Tase, N., Sasa, K., Takahashi, T., and Nagashima, Y.: Estimation of groundwater residence time using the ${ }^{36} \mathrm{Cl}$ bomb pulse, Ground Water, 49, 891-902, https://doi.org/10.1111/j.1745-6584.2010.00795.x, 2011.

Tsuchi, R.: Groundwater and springs of Fuji Volcano, Japan, in: Fuji Volcano, Yamanashi Institute of Environmental Sciences, Yamanashi, edited by: Aramaki, S., Fujii, T. Nakada, S., and Miyaji, N., Japan, 375-387, 2007.

Tsuya, H.: 1 : 50,000 Geologic map of Mt. Fuji, Geological Survey of Japan, 1968.

Wang, Q., Garrity, G. M., Tiedje, J. M., and Cole, J. R.: Naïve Bayesian classifier for rapid assignment of rRNA sequences into the new bacterial taxonomy, Appl. Environ. Microbiol. 73, 52615267, https://doi.org/10.1128/AEM.00062-07, 2007.

Watanabe, K., Takebe, Y., Sode, N., Igarashi, Y., Takahashi, H., and Dokiya, Y.: Fog and rain water chemistry at Mt. Fuji: A case study during the September 2002 campaign, Atmos. Res., 82, 652-662, https://doi.org/10.1016/j.atmosres.2006.02.021, 2006.

Wels, C., Cornett, R. J., and Lazerte, B. D.: Hydrograph separation - A comparison of geochemical and isotopic tracers, J. Hydrol., 122, 253-274, https://doi.org/10.1016/0022-1694(91)90181-G, 1991.

Whitman, W. B., Coleman, D. C., and Wiebe, W. J.: Prokaryotes: The unseen majority, P. Natl. Acad. Sci. USA, 95, 6578-6583, 1998.

Yasuhara, M., Kazahaya, K., and Marui, A.: An Isotopic study on where, when, and how groundwater is recharged in Fuji volcano, central Japan, in: Fuji Volcano, Yamanashi Institute of Environmental Sciences, edited by: Yamanashi, Aramaki, S., Fujii, T., Nakata, F., and Miyaji, N., Japan, 389-405, 2007.

Zhou, Y., Kellermann, C., and Griebler, C.: Spatio-temporal patterns of microbial communities in a hydrologically dynamic pristine aquifer, FEMS Microbiol. Ecol., 81, 230-242, https://doi.org/10.1111/j.1574-6941.2012.01371.x, 2012. 